\title{
Mesobathic chondrichthyes of the Juan Fernández seamounts: are they different from those of the central Chilean continental slope?
}

\author{
Isabel Andrade \& Germán Pequeño \\ Universidad Austral de Chile, Instituto de Zoología “Ernst F. Kilian”, Casilla 567, Valdivia, Chile. Fax: 56-63-221315; \\ isabelandradec@gmail.com; gpequeno@uach.cl
}

Received 12-IX-2006. Corrected 25-IV-2007. Accepted 10-VIII-2007.

\begin{abstract}
We compared the geographic distribution of groups of chondrychthid fishes of two physically proximal, although geographically different, regions that include the Juan Fernández seamounts and the central Chilean continental slope, both sampled at mesopelagic and mesobenthonic depths. The ridge is in the Nazca Plate, while the slope region in on the South American Plate, and is closer to the South American continent. We found six species of Chondrichthyes for the seamounts (four orders, four families). The slope sampling produced ten species of Chondrichthyes, of which Torpedo tremens De Buen 1959, was the only species in common with the Juan Fernández area. There are clear differences between the Chondrichthyes of the two regions. These fisheries require adequate administrative modes. Rev. Biol. Trop. 56 (1): 181-190. Epub 2008 March 31.
\end{abstract}

Keywords: ichthyogeography, Chondrichthyes, seamounts, Juan Fernández, slope, Chile.

Few ichthyogeographic studies have been carried out in Chile, limiting the advancement of scientific, technological and educational applications of ichthyology in the country. The present study is a contribution to this field, from both basic and applied perspectives, with particular emphasis on two populations of cartilaginous fishes occupying mesobathic habitats near the SE Pacific border of Chile. One of these habitats is part of the Juan Fernández archipelago, and specifically the chain of seamounts stretching to the west of these islands on the Nazca tectonic plate. A commercial fishery is operated in this region. At a relatively short distance east of this submarine cordillera region lies the Chilean continental shelf and slope, which also supports an important commercial fishery. The latter region is situated on the South American tectonic plate, and is separated from the former region by a trench of abyssal depth. Basic information is lacking on the comparative taxonomic makeup of the Chondrichthyes of these two regions, which is also of practical importance in relation to catches obtained in the commercial fisheries; i.e.) it is unknown whether these fisheries are harvesting a single resource, or resources specific to each region.

The study of Chondrichthyes in Chile was begun by Abbot Juan Ignacio Molina (1782); followed by C. Pérez Canto (1886), who described 11 species of sharks from the Chilean coast. Although the number of publications on sharks in Chile increased notably during the $20^{\text {th }}$ century, little is known in general on their comparative biology, behavior, and geographic distribution, the latter area being important in determining spatio/temporal relationships among these fishes, and the dynamics of their community assemblages.

Some studies which have contributed data on fish biogeography in Chile, without making comparative studies between specific zones, include that of Mann (1954) on the sharks of Chile, and later that of Meléndez and Meneses (1989) on Chondrichthyes between 
Arica (18 30’ S) and Isla Mocha (38 30’ S). There are only three studies (a series) which have addressed the comparative geographic distribution of Chondrichthyes in Chile, including Pequeño (1983), Pequeño et al. (1990), Pequeño and Lamilla (1993).

Fifty years after the seminal study by Mann (1954), Pequeño and Sáez (2004) remarked on the lack of regional ichthyological studies, as well as the fact that existing biogeographic studies of Chondrichthyes were centered on the southern half of Chile. The present study represented an attempt to solve one of a number of problems in this field which has been of interest to us, including determination of whether or not the species composition of Chondrichthyes the Chilean continental slope was the same as that occupying the nearby seamounts of the Juan Fernández ridge. To this end, we carried out mesobathic and mesopelagic sampling in both regions, and identified the Chondrichthyes from the fish assemblages sampled.

\section{MATERIALS AND METHODS}

Sampling was carried out near the seamounts between May and August 2002 in the commercial trawl fishery for "orange roughy" Hoplosthethus atlanticus Collet 1889. Fishing was carried out at depths of about 300 to $500 \mathrm{~m}$ in an area between $33^{\circ}$ to $34^{\circ} \mathrm{S}$, and $77^{\circ}$ to $78^{\circ}$ $\mathrm{W}$, corresponding these coordinates to the seamounts of the Juan Fernández submarine ridge, located in the central easternmost zone of the Nazca Plate (González-Ferrán 1987) (Fig. 1). Data for continental slope fishes was obtained from Henríquez et al. (1981), representing Chondrichthyes from between Valparaiso $\left(33^{\circ} 02^{\prime} \mathrm{S}, 71^{\circ} 37^{\prime} \mathrm{W}\right)$ and San Antonio (33 $54^{\circ}$ $\left.\mathrm{S}, 71^{\circ} 41^{\prime} \mathrm{W}\right)$, a coastline which is perpendicular to the study area at a distance of $652 \mathrm{Km}$ on the Southamerican Plate. Data comparisons were made between species groups obtained at similar depths. All samples were preserved in $10 \%$ seawater-formalin, and later transferred to $70 \%$ alcohol. Samples analyzed during the study were deposited in permanent marine fish collections of the Instituto de Zoología de la Universidad Austral de Chile (IZUA-PM). Fish specimens were measured to the nearest $\mathrm{mm}$ following the methods of Compagno (1984) for selachians, De Buen (1959) for batoids and Hardy and Stehmann (1990) for chimaeras. Following identification to species, a comparative analysis was made on spatial distribution patterns and their ichthyogeographic relations, followed by a ranking of the degree of similarity between the two different geographic areas of the study illustrated by a table of presence (1) or absence (0) of families, genera, and species (Table 1).

Data were analyzed using the Jaccard (1912) index, which allows the use of binary data and is considered to be one of the least complex measures for ecological studies (Boesch 1977). The value of unity (1) is obtained in cases of complete similarity, and

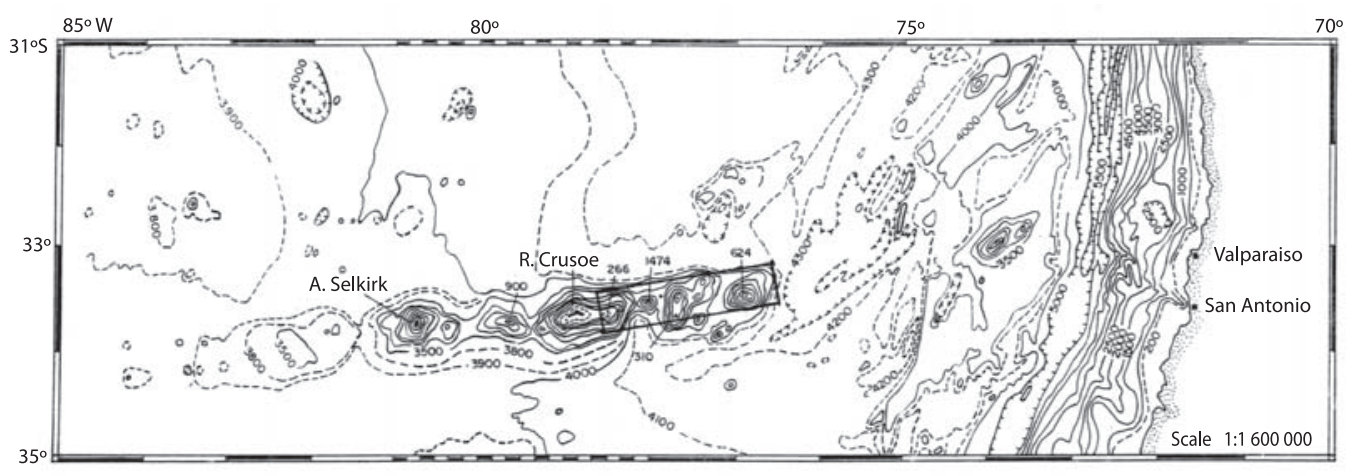

Fig. 1. Geographic area involved in this study. The rectangle shows the zone in which the samples were obtained, within the Juan Fernández submarine ridge (Modified from Morales 1984). 
TABLE 1

Families and species of chondrichthyans present (+) or absent (-) in the Juan Fernández seamounts and Central Chilean Continental Slope

Taxa

Juan Fernández seamounts

Valparaíso-San Antonio

Squalidae

Centroscyllium nigrum Garman, 1899

Centroscyllium granulatum Günther, 1887

Etmopterus granulosus (Günther, 1880)

Squalus mitsukurii Jordan y Snyder, 1903

Squalus acanthias (Smith y Radcliffe, 1912)

Aculeola nigra De Buen, 1959

Scyliorhinidae

Apristurus brunneus (Gilbert, 1892)

Apristurus nasutus De Buen, 1959

Torpedinidae

Torpedo tremens De Buen, 1959

Chimaeridae

Hydrolagus macrophthalmus De Buen, 1959

Hydrolagus pallidus Hardy y Stehmann, 1990

Pseudorajidae

Sympterygia lima (Poeppig, 1835)

Psammobatis scobina (Philippi, 1857)

Rajidae

Dipturus chilensis (Guichenot, 1848)

Gurgesiellidae

Gurgesiella furvescens De Buen, 1959

the null value $(0)$ is obtained at maximum dissimilarity (Magurran 1989).

The equation used is:

$$
\mathrm{q}=\mathrm{c} /(\mathrm{a}+\mathrm{b}+\mathrm{c})
$$

Where $\mathrm{q}$ is the similarity index, the number of families, genera, or species present in area A is represented by $\mathrm{a}, \mathrm{b}$ is the number of corresponding taxa in area $\mathrm{B}$, and $\mathrm{c}$ is the total number corresponding taxa in both areas or taxa which are common to both areas. This method is simplified in that it does not include abundance values by species; it emphasizes the differences between groups, ignoring cases with

no correspondence (Pimentel 1979, Pequeño 1983), which makes it well adapted for interpretation of the data of the present study.

\section{RESULTS}

The morphometric analyses permitted clarification of the taxonomic status of some of the specimens under study, as in the case of a specimen of Apristurus brunneus. The presence of Hydrolagus pallidus was also noted for the Chilean coast, whereas it had only been previously described from the NE Atlantic coast (Andrade and Pequeño 2006). Six species of 
Chondrichthyes are now reported from the mesobathyal region over the Juan Fernández seamounts, distributed among four orders and four families (Table 2).

Families: a total of seven families of Chondrichthyes are now listed from the two areas studied (Table 1). Only four families are represented by species in both areas, including the Squalidae, Scyliorhinidae, Torpedinidae and Chimaeridae. The seamounts did not exclusively host any given family, while the Chilean coast had three families which were not present over the seamounts, including the Pseudorajidae, Rajidae and Gurgesiellidae. For this reason the Jaccard Index remained practically at a middle value.

The family containing the largest number of genera (four) was the Squalidae, which was also the family with the largest number of species (six). There were three families each containing a single genus, including the Torpedinidae, Rajidae and Gurgesiellidae, each containing one species.

Genera: assemblages of Chondrichthyes from the two regions being compared had a total of 12 genera as listed in Table 3. Of all the genera, only one (Etmopterus) was

TABLE 2

Systematic brief of the mesobathic chondrichthyofauna found in the Juan Fernández seamounts

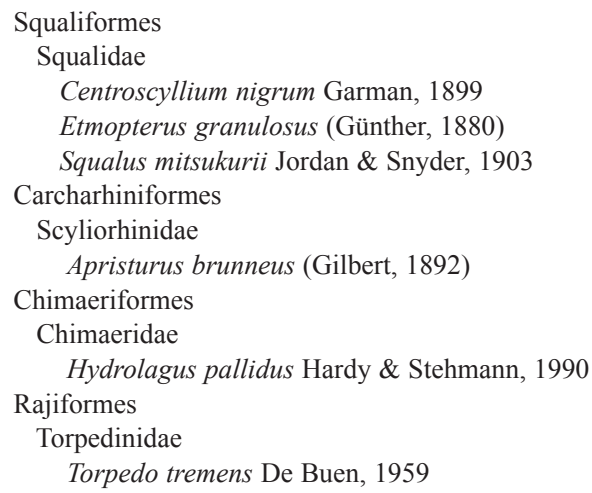

TABLE 3

Calculation of the Jaccard's Index for families, genera and species, between mesobathic chondrichthyans from the Juan Fernández seamounts and the Central Chile Slope

$\begin{array}{lcccc} & \mathrm{a} & \mathrm{b} & \mathrm{c} & \mathrm{q} \\ \text { Families } & 0 & 3 & 4 & 0.57 \\ \text { Genera } & 1 & 6 & 5 & 0.41 \\ \text { Species } & 5 & 9 & 1 & 0.06\end{array}$

unique to the Juan Fernández seamount area, and six were unique to the continental slope, including Halaelurus, Aculeola, Psammobatis, Sympterygia, Raja and Gurgesiella. On the other hand, genera such as Centroscyllium, Apristurus, Squalus, Torpedo and Hydrolagus were common to both areas.

There was no dominance assignable to any of these genera, since five of the genera were represented by two species each, and the seven remaining genera by one species each. The preceding produced a Jaccard index only slightly lower than that obtained on the basis of families, and thus on the generic level there was still no clear difference observed between the two areas being compared.

Species: a total of 15 species of Chondrichthyes were identified from in the two areas being compared. Of all the species reported, only Torpedo tremens (family Torpedinidae) (Fig. 2) occurred in both areas. The present study recovered six species of Chondrichthyes from the seamount area, including Centroscyllium nigrum, Etmopterus granulosus, A. brunneus, Squalus mitsukurii, T. tremens and $H$. pallidus, with five of these species unique to the area; the central Chilean slope produced ten species, nine which were not found in the seamount area.

Since both areas had only one species in common, the value of the Jaccard index was very close to the null value (0.06), showing the great difference encountered in comparison of species composition between the two areas. 


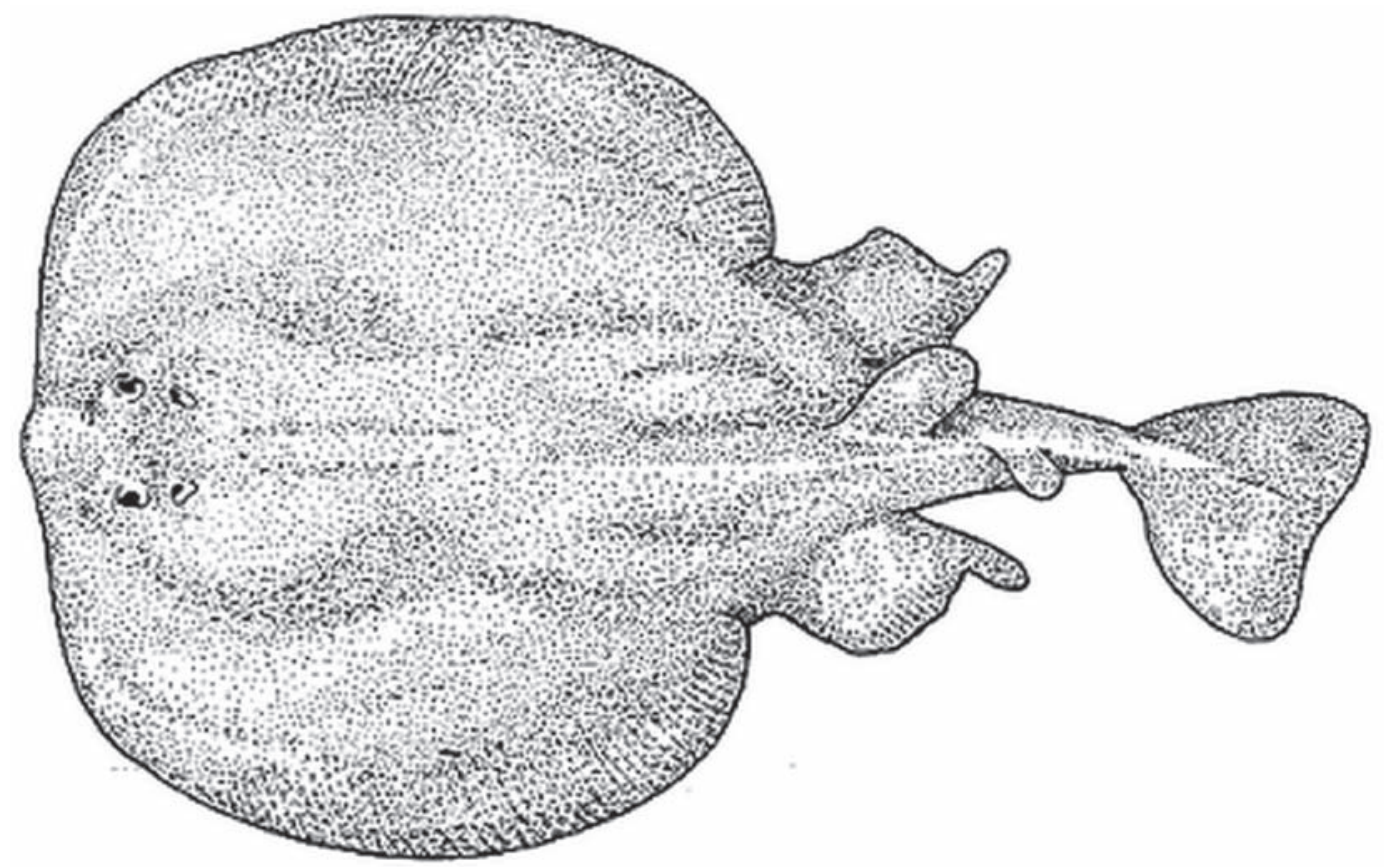

Fig. 2. Torpedo tremens, the only one species common to both studied areas. Adult of about $58 \mathrm{~cm}$ TL. (Modified from De Buen 1959).

Geographic distribution of Chondrichthyes found over the Juan Fernández seamounts: A brunneus: Washington Coast; Santa Barbara Channel, California (Springer 1979); E Pacific: La Jolla, California; British Columbia, Canada to northern Baja California, México and probably south of Panama, as well as Ecuador and Peru, at depths from 33 to 950 m (Compagno 1984); Meléndez and Meneses (1989) extended this distribution to $35^{\circ} 38^{\prime} \mathrm{S}$ in Bahía Chanco, Chile.

C. nigrum: Central Pacific; Hawaiian Islands; E Pacific; southern California, Panama, Cocos I., Colombia, Ecuador, northern and central Chile, Galapagos Is. This species occurs from depths of 400 to $1143 \mathrm{~m}$ (Compagno 1984, Pequeño et al. 1990).

E. granulosus: Western S Atlantic: Southern Argentina, Malvinas Is., Magellan Straits; SE Atlantic: Cape of Good Hope, S Africa; SE Pacific; southern Chile, at depths from 220 to 637 m (Compagno 1984, Pequeño et al. 1990). Meléndez and Meneses (1989), extended its distribution northward from the S Pacific to $26^{\circ} 20^{\prime} \mathrm{S}$ and also extended its depth to $950 \mathrm{~m}$.

S. mitsukurii: Pequeño and Toledo (1994) reported this species from two miles off San Juan Bautista (Cumberland Bay) and Robinson Crusoe Island (Juan Fernández archipiélago). NE Pacific; Japan, Korea, China, probably Taiwan and Viet Nam, also on NW Pacific seamounts, SE Pacific: possibly New Zealand. Central Pacific: Hawaiian Is. (Chen et al. 1979, Compagno 1984). There are similar "horned sharks", which may be identical to this species in Tasmania and Australia, the Philippines, S. Africa and in the western and eastern Atlantic which are not conspecific with $S$. blainvillei. SE Pacific; northern Chile, at depths of $190 \mathrm{~m}$ although it can range to different depths based on the habitat occupied, extending from four to $740 \mathrm{~m}$ (Compagno 1984). This species is common at the Juan Fernández Islands (Pequeño and Sáez 2000).

T. tremens: De Buen (1959) occurred in the pre-abyssal zone off Valparaíso. Parín and 
Kotlyar (1985) cited it at $37^{\circ} 22^{\prime} \mathrm{S} ; 8^{\circ} 27^{\prime} \mathrm{W}$ at a depth of 20-60 m.

H. pallidus: Previously cited only for the NE Atlantic at depths between 1200 and 2075 m (Hardy and Stehmann 1990).

\section{DISCUSSION}

This ichthyogeographic study, representing three of the four more eastern seamounts of the Juan Fernández ridge and the Chilean slope area between Valparaíso and San Antonio, showed clearly that geographic proximity did not necessarily produce taxonomic similarity among the species of Chondrichthyes occupying these two areas.

We began by analyzing a higher level taxonomic range (family), at which we expected a high level of similarity between the two areas since this range contains earlier evolutionary differentiation compared with lower hierarchies such as species. The Jaccard index at this level produced a middle value, where the family Squalidae was better represented at the species level, which suggested a greater adaptive character of these species for the various conditions within the environment. As the taxonomic range decreased, the Jaccard index decreased, at the generic level becoming a value lowers than the middle, with Etmopterus the only genus having species unique to the seamounts as compared with the slope area. When analyzed to the species level, the differences in the Chondrichthyes were maximal between the study areas.

When comparing the distributional results of the present study with the overall distributions of each species from the study areas, a pattern emerges. Although A. brunneus is found throughout the northern, central and SE Pacific with habits closer to the coast (Compagno 1984), Sato et al. (1999) also mentioned it as an inhabitant of trenches and ridges in the polar seas. These authors stated that this species was commonly discarded from catches of the orange roughy in New Zealand. It was therefore not unusual to find it in our study area. This species feeds mostly on decapods crustaceans; bony fishes also form an important part of its diet (Cortés 1999).

C. nigrum, as with the previous species, only occurs in the northern, central, and SE Pacific, in both coastal and oceanic habits, and can also be found on the slopes of oceanic and coastal islands (Compagno 1984), it was one of the more abundant fishes over the seamounts in the present study.

The distribution of E. granulosus is limited to the southern hemisphere, where it is not only found in the SE Pacific, but also on the eastern and western sides of the S Atlantic (Compagno 1984); this species appears to be temperaturelimited, since its distribution always appears to be associated with cold water masses, and is dominant in Antarctic intermediate water. Its presence in the study area may be due to the fact that there is a confluence of water masses, among which occur the subtropical waters which is highly influenced by the presence of Antarctic intermediate water (Silva 1985). The diet of this species consists mainly of bony fishes, cephalopods and decapods crustaceans (Cortés 1999).

S. mitsukurii is a cosmopolitan species, with a poorly defined distribution pattern, nor does it have a common depth range, being found between four and $740 \mathrm{~m}$ among the various environments in which it occurs. This suggests that the species tolerates a wide range of temperatures, which in turn allows it to adapt to various different habitats. Their fusiform bodies, with large, rigid fins at acute angles suggest it has a hydrodynamic advantage which makes it an efficient swimmer and predator. This species feeds mainly on bony fishes, as well as on cephalopods and crustaceans (Compagno 1984).

There have been few records of $T$. tremens; this fish has mostly been found in the SE Pacific, being mainly described from Chile. Data from FishBase (Froese and Pauly 2005) also list it from the coasts of Costa Rica and Ecuador. Its diet is composed mainly of invertebrates and bottom fishes.

Hardy and Stehmann (1990) described H. pallidus from the NE Atlantic; the present 
study extends this range to the SE Pacific coast, and specifically to the seamounts near the Juan Fernández Archipelago to depths between about 300 and $500 \mathrm{~m}$, thus broadly extending the geographic range of this species.

The Jaccard Index values at the species level show clear differentiation between the two areas of study, although leaving the new question of why such a difference should exist. The data also show the importance of being able to differentiate between the environments in spite of their proximity to each other.

It has long been known that the continental slope is rich in species diversity, suggesting that it is a favorable region for supporting many taxa; it may not be the "best" available habitat for all species, although having a number of individually favorable characteristics in comparison with other extensive marine habitats.

The habitats provided by seamounts (which were defined as elevations from the sea-floor with more than $1000 \mathrm{~m}$ height and with a top limit up to their tip, Menard 1964 In Rogers 1994) are also unique; although as yet poorly researched, they have been found to support a number of commercially valuable fisheries resources such as the orange roughy, H. atlanticus (Smith 2001, Gubbay 2003, Morato et al. 2004).

The present study recognizes two geographic areas having individual oceanographic features (physical parameters such as temperature, salinity, and presence of water masses) and geology (origin, structure, and relief) which separates them environmentally because the seamounts are generally of vulcanic origin (Epp y Smoot 1989) while the slope has been originated by tectonic movements. Thus these environments each contain a contrasting diversity of their fish fauna, with the central Chilean slope habitat of higher diversity. This fact was interesting to us because of their relative proximity to each other at the same latitude.

The existence of a species common to both habitats, such as the epibenthic T. tremens was not very significant when compared with the richness in families existing between the two habitats. However, the existence of so few batoids in the samples was probably due to limitations of the sampling method.

Because of the given information, the difference between the two groups of fishes found can be explained by several factors. At present, the seamounts are known for having high biological productivity which makes them attractive to large pelagic fishes and sharks (Muhlia-Melo et al. 2003). This productivity, based on planktonic organisms, forms an important diet for fishes and top predators (Gubbay 2003). Two hypotheses have been proposed to explain the existence of high biological productivity around the seamounts, including; i) the existence of local upwelling which imports nutrients which support primary productivity, and ii) drift plankton is trapped and retained in Taylor columns (closed circulation systems; Gubbay 2003).

This last paragraph is supported on the basis that great flux deviations happen around simple obstacles (Trasviña et al. 2003); and it is known that the seamounts interrupt the water fluxes and then affect the hydrography and the current systems in its inmediate vecinity and still further (Gubbay 2003), besides the growup of the already mentioned Taylor's columns, which generate upwelling and downwelling (Trasviña et al. 2003).

Thus, water circulation processes occurring around the seamounts (Trasviña et al. 2003) may produce an environment equally favorable to that of the continental slope which undergoes enrichment from coastal upwelling. Thus, despite they are not too far from the continental coastline, the seamounts of this study suffer the influence of the Chile-Perú or Humboldt current (with their coastal and oceanic branches and the Perú counter-current), as well as that one of the dephts over $4000 \mathrm{~m}$, and the more than $500 \mathrm{Km}$ of linear distance that separate it from the continent, becoming high selective barriers for the possible exchange of their respective biotas (Protti 1997).

On other hand, dense aggregations of fishes have been recorded over and around seamounts (Tracy and Horn 1999 In Smith 2001) which make these areas easy targets for commercial 
fisheries, particularly those employing trawls which affect a broad variety of organisms. Various species of Chondrichthyes caught in this fishery are often discarded.

Fisheries exploitation of the seamount habitats raises the question of the sustainability of their resources over time. Most of the species of fishes common in these environments are latematuring, have slow growth, and low mortality rates, which make them comparatively more vulnerable to commercial exploitation (Jenings et al. 1998, 1999, Russ and Alcala 1998, Musick 1999, Denney et al. 2002, all of them In Morato et al. 2004), making possible the occurrence of local extinction of some species.

Based on present considerations, we recommend protective steps be taken for the conservation of fisheries resources from seamount habitats because: i) these may contain species as yet unknown or little studied by science, ii) some species inhabiting the seamounts are endemic and thus may be lost forever if adversely affected by fishing efforts, iii) some fish species may use the seamounts for spawning activity, iv) human activity is directly proportional to loss of biodiversity of the seamounts, v) many of the species which inhabit the seamounts have great longevity, slow growth and late maturation, vi) the seamounts may act as "stepping stones" for the dispersion of coastal species, and vii) the seamounts may act as centers of speciation.

Seamount habitats have recently come into focus as interesting communities with regard to their support of biological communities, both as a group and individually and, although little is known about these ecosystems, the lack of knowledge about them suggests a need for future research into their basic and applied environmental significance. Taxonomic knowledge of their fish fauna is fundamental for their description and for making biogeographic comparisons, as well as for the advancement of knowledge related to their ecology, biogeography, and resource management.

Based on fisheries sampling surveys, the suite of chondrichthyes from the eastern sector of the Juan Fernández undersea cordillera is different from that of the Chilean continental slope, in agreement with the hypothesis proposed in this study. The finding of a specimen of Hydrolagus pallidus, besides notably extending the geographical distribution of the species, reiterates the need for implementing new studies on the holocephalids of Chilean waters, a topic little known to science. The catch of Torpedo tremens in the eastern sector of the Nazca Plate indicates that coexistence of individuals of a single species is possible in this area as well as in the more westerly sector of the South American Plate. Studies must be carried out which allow improving knowledge of the taxonomic composition, biology, ethology, and ecology of individuals and communities which inhabit this type of environment. This thesis presents a spread of new possibilities for the development of a new scientific projects, including the ichthyology of the region under consideration.

\section{ACKNOWLEDGMENTS}

We appreciate laboratory work by León Matamala (Universidad Austral de Chile), and Library advice by Patricia Pacheco (P. Universidad Católica de Valparaíso) and Jeannette Santana (Universidad de Valparaíso). These are partial results of Project CIMAR 6 ISLAS (Comité Oceanográfico Nacional, CONA) and DID-S-2005-03 to the co-author.

\section{RESUMEN}

Se realizó un estudio de distribución geográfica comparativa entre conjuntos de peces condrictios de dos sectores geográficamente cercanos, pero geológicamente distintos, el sector este de la cordillera sumergida de Juan Fernández y el talud continental de Chile central, a profundidades mesopelágicas y mesobentónicas. La cordillera está sobre la placa de Nazca, el talud en la Sudamericana. Comparamos familias, géneros y especies, mediante el índice de Jaccard. Hay seis especies de condrictios en los montes submarinos (cuatro órdenes y cuatro familias). El talud tiene diez especies, y únicamente comparte con la cordillera a Torpedo tremens De Buen 1959. Estos condrictios requieren modos administrativo-pesqueros adecuados. 
Palabras claves: Ictiogeografía, condrictios, cordillera sumergida, Juan Fernández, talud, Chile.

\section{REFERENCES}

Andrade, I. \& G. Pequeño. 2006. Primer registro de Hydrolagus pallidus Hardy y Stehmann, 1990 (Chondrichthyes: Chimaeridae) en el océano Pacífico, con comentarios sobre los holocéfalos de Chile. Rev. Biol. Mar. Oceanogr. Valparaíso 41: 111-115.

Boesch, D.F. 1977. Application of numerical classification in ecological investigations of water pollution. Ecol. Res. Series, EPA-600/3-77-033, Corvallis, Oregon, USA.

Chen, C., T. Taniuchi \& Y. Nose. 1979. Blainville's dogfish, Squalus blainvillei, from Japan, with notes on S. mitsukurii and S. japonicus. Jpn. J. Ichthyol. 26: 26-42.

Compagno, J.V. 1984. FAO Species catalogue, 4, Sharks of the world. An annotated and illustrated catalogue of shark species known to date. Part 1. Hexanchiformes to Lamniformes. FAO Fish. Synop. 1: 1-249.

Cortés, E. 1999. Standardized diet compositions and trophic levels of sharks. ICES J. Mar. Sci. 56: 707-717.

De Buen, F. 1959. Notas sobre Ictiología Chilena, con descripción de dos nuevas especies. Rev. Biol. Mar. Valparaíso 9: 257-269.

Epp, D. \& N.C. Smoot. 1989. Distribution of seamounts in the North Atlantic. Nature 337: 254-257.

González-Ferrán, O. 1987. Evolución geológica de las Islas chilenas en el océano Pacífico, p. 37-54. In J.C. Castilla (ed.). Islas Oceánicas Chilenas: conocimiento científico y necesidades de investigación. Universidad Católica de Chile, Santiago, Chile.

Gubbay, S. 2003. Seamounts of the North- East Atlantic. WWF Germany, Frankfurt am Main, Germany.

Hardy, G.S. \& M. Stehmann. 1990. A new deep-water ghost shark, Hydrolagus pallidus n.sp. (Holocephali, Chimaeridae), from the Eastern North Atlantic, and redescription of Hydrolagus affinis (Brito Capello, 1867). Arch. Fisch. Wiss. 40: 229-248.

Henríquez, G., L. Rodríguez \& I. Kong. 1981. Exploración y prospección de recursos pesqueros del talud continental. Corporación de Fomento de la Producción, Instituto de Fomento Pesquero, Chile AP 81: 1- 60.
Jaccard, P. 1912. The distribution of the flora in the alpine zone. New Phytol. 11: 37-50.

Magurran, A.E. 1989. Diversidad Ecológica y su Medición. Vedrá, Galicia, España.

Mann, G. 1954. La vida de los peces en aguas chilenas. Instituto de Investigaciones Veterinarias y Universidad de Chile, Santiago, Chile.

Meléndez, R. \& D. Meneses. 1989. Tiburones del Talud Continental recolectados entre Arica $\left(18^{\circ} 30^{\prime}\right.$ S) e Isla Mocha (38³0' S). Chile. Invest. Mar. Valparaíso 17: 3-37.

Molina, J.I. 1782. Saggio sulla Storia Naturale del Cile. Bologna, Italy.

Morales, E. 1984. Geografía de los fondos marinos del mar chileno. Colección Geografía de Chile, Instituto Geográfico Militar, Santiago, Chile.

Morato, T., W.L. Cheung \& T.J. Pitcher. 2004. Vulnerability of seamount fish to fishing: Fuzzy analysis of lifehistory attributes, p. 51-60. In T. Morato \& D. Pauly (eds.). Seamounts: Biodiversity y Fisheries. Fish. Centre Res. Report, Otawa, Canadá.

Muhlia-Melo, A., P. Klimley, R. González-Armas, S. Jorgensen, A. Trasviña-Castro, J. Rodríguez-Romero \& A. Amador Buenrostro. 2003. Pelagic fish assemblages at the Espíritu Santo seamount in the Gulf of California during El Niño 1997-1998 and non-El Niño conditions. Geof. Intern. 42: 473-481.

Parín, N.V. \& A.N. Kotlyar. 1985. La rayas del género Torpedo en los mares abiertos del Pacífico sur oriental. Vopr. Ikhtyol. 25: 207-718.

Pequeño, G. 1983. La condrictiofauna de las regiones de Chile y California-Oregon: Comparación preliminar. Conferencia Internacional sobre Recursos Marinos del Pacífico, Universitarias, Santiago, Chile.

Pequeño, G., J. Rucabado \& D. Lloris. 1990. Tiburones comunes a las costas de Chile, California-Oregon y Namibia-Sud África. Rev. Biol. Mar. Valparaíso 25: 65-80.

Pequeño, G. \& J. Lamilla. 1993. Batoídeos comunes a las costas de Chile y Argentina-Uruguay (Pisces: Chondrichthyes). Rev. Biol. Mar. Valparaíso 28: 203-217.

Pequeño, G. \& H. Toledo. 1994. Diferencias entre embriones de término de Squalus acanthias Linnaeus, 1758 y S. mitsukurii Jordan and Snyder, 1903 (Chondrichthyes, Squalidae). Rev. Biol. Mar. Valparaíso 29: 137-145. 
Pequeño, G. \& S. Sáez. 2000. Los peces litorales del Archipiélago de Juan Fernández (Chile): endemismo y relaciones ictiogeográficas. Invest. Mar. Valparaíso 28: $27-37$.

Pequeño, G. \& S. Sáez. 2004. Peces Marinos Comunes del Litoral de Valdivia. Guía de reconocimiento para efectos prácticos. Corporación Ambiental del Sur, Surambiente, Valdivia, Chile.

Pérez Canto, C. 1886. Estudio sobre algunos escualos de la costa de Chile. El Pequeño Mercurio, Valparaíso, Chile.

Pimentel, R. 1979. Morphometrics. Kendall/Hunt, Dubuque, Iowa, USA.

Protti, M. 1997. Los peces de la familia Labridae en las Islas oceánicas chilenas. Comparación, distribución y relaciones ictiogeográficas (Osteichthyes: Perciformes). Tesis de Doctorado, Universidad Austral de Chile, Valdivia, Chile.

Rogers, A.D. 1994. The Biology of Seamount. Adv. Mar. Biol. U.K. 30: 305-350.

Sato, K., K. Nakaya \& A. Stewart. 1999. A new species of deep-water catshark genus Apristurus from New Zealand waters (Chondrichthyes: Scyliorhinidae). J. Roy. Soc. N.Z. 29: 325-335.
Silva, N. 1985. Algunas características físicas y químicas de las masas de agua alrededor de las islas Robinson Crusoe y Santa Clara (Archipiélago de Juan Fernández), p. 35-41. In P. Arana (ed.). Investigaciones Marinas en el Archipiélago de Juan Fernández. Universidad Católica de Valparaiso, Valparaíso, Chile.

Springer, S. 1979. A Revision of the catsharks, family Scyliorhinidae. NOAA Technical Report NMFS Circular 422: 1-151.

Trasviña, A., G. Gutiérrez de Velasco, A. Valle-Levinson, R. González-Armas, A. Muhlia-Melo \& M. A. Cosio. 2003. Hydrographic observations of the floor in the vicinity of a shallow seamount top in the Gulf of California. La Paz, Baja California, Mexico.

\section{ELECTRONIC REFERENCES}

Froese, R. \& D. Pauly. 2005. FishBase. World Wide Web electronic publication (www.FishBase.org; downloaded 01 January 2005)

Smith, P. 2001. Managing biodiversity: invertebrate by-catch in seamount fisheries in the New Zealand Exclusive Economic Zone. Blue Millennium, Managing Global Fisheries for Biodiversity, Victoria (www.worldfish. org/Blue\%20Millennium\%20PDFs/Conference Agenda.pdf; downloadedJune 25, 2005). 